
available copy to permit the broadest possiblo availability.

\title{
Evaluation of the ${ }^{63} \mathrm{Cu}$ Activation Foil for Determining the Neutron Dose in the Energy Range of $1 \mathrm{eV}$ to $1 \mathrm{MeV}$
}

\author{
Y. Eisen \\ D. G. Vasilik \\ R. J. Brake
}

DISCLAMER

This report. was prepared as an account of work sponsored by an agency of the United States Government. Neither the United States Government nor any agency thereof, nor any of their employees, makes any warranty, express or implied, or assumes any legal liability or responsibility for the accuracy, completeness, or usefulness of any information, apparatus, product, or process disclosed, or represents that its use would not infringe privately owned rights. Reference herein to any specific commercial product, process, or service by trade name, trademark, manufacturer, or otherwise does not necessarily constitute or imply its endorsement, recommendation, or favoring by the United States Government or any agency thereof. The views and opinions of authors expressed herein do not necessarily state or refleat those of the United States Government or any agency thereof. 
EVALUATION OF THE ${ }^{63} \mathrm{Cu}$ ACTIVATION FOIL FOR DETERMINING THE NEUTRON DOSE IN THE ENERGY RANGE OF

$1 \mathrm{eV}$ To $1 \mathrm{MeV}$

by

Y. Eisen, D. G. Vasilik, and R. J. Brake

\section{ABSTRACT}

The appropriateness of the ${ }^{63} \mathrm{Cu}$ activation foil for determining the neutron dose in the energy region from $1 \mathrm{eV}$ to $1 \mathrm{MeV}$ has been investigated for spectra of seven different criticality accident configurations. A program was written for folding the published spectra with the ${ }^{63} \mathrm{Cu}$ activation cross sections and with the fluence-to-dose or kerma conversion factors. It is shown that for these spectra the neutron dose and kerma result primarily from the energy region above $15 \mathrm{keV}$ whereas the measured ${ }^{64} \mathrm{Cu}$ activity is mainly determined by the fluence in the region between $1 \mathrm{eV}$ and $15 \mathrm{keV}$. Uncertainties in the fluence spectrum in the low-energy region between $1 \mathrm{eV}$ and $15 \mathrm{keV}$, which in reality do not affect the dose contribution, might lead to large deviations in the measured ${ }^{64} \mathrm{Cu}$ activity and hence to the derived dose in the $1 \mathrm{eV}$ to $1 \mathrm{MeV}$ range. Use of ${ }^{10} \mathrm{~B}$ shielding for attenuating the fluence in the $1-\mathrm{eV}$ to $15-\mathrm{keV}$ region was evaluated, leading to the conclusion that the necessary amount of boron material is unacceptably large and would appreciably increase the cost of the dosimeter currently used at Los Alamos. The lower limit of neutron detectability would also be increased. 


\section{INTRODUCTION}

${ }^{6}{ }^{63} \mathrm{Cu}$ activation foil is used in the Los Alamos criticality dosimeter to estimate the neutron dose in the energy region from $1 \mathrm{eV}$ to $1 \mathrm{MeV}$. 1 The foil is used both in the Personnel Heutron Dosimeter (PND) and in the Area Dosimeter (LACD) and is covered with cadmium for thermal neutron removal. The epithermal neutrons react with ${ }^{63} \mathrm{Cl}$ as follows:

$$
{ }^{63} \mathrm{Cu}(n, \gamma)^{64} \mathrm{Cu}
$$

The ${ }^{64} \mathrm{Cu}$ is a positron emitter $\left(E_{\max }=0.656 \mathrm{MeV}\right)$ and has a $12.8 \mathrm{~h}$ half-life. Gamma rays from positron annihilation are measured with a $\mathrm{Ge}(\mathrm{Li})$ detector for the determination of the ${ }^{64} \mathrm{Cu}$ activity. The ${ }^{65} \mathrm{Cu}$ present in the foil does not interfere with the above measurement. The activation product, ${ }^{66} \mathrm{Cu}$, is short-lived (5.1 min half-life) and the counting is performed after ${ }^{66} \mathrm{Cu}$ decays and no longer interferes with the measurement of ${ }^{64} \mathrm{Cu}$ activity.

The cross section for reaction (1) can be separated into a decreasing component and a resonance component. There are two very significant resonances at $580 \mathrm{eV}$ and at about $2 \mathrm{keV} .^{2}$

The objectives for this study were to investigate

- the appropriateness of the ${ }^{63} \mathrm{Cu}$ activation foil for determining the neutron dose in the $1-\mathrm{eV}$ to $1 \mathrm{HeV}$ energy region for commonly described criticality configurations and

- the dominant energy regions contributing to the total neutron dose.

\section{SPECTRA INVESTIGATED}

The utility of a ${ }^{63} \mathrm{Cu}$ activation foll for determining the neutron dose between $1 \mathrm{eV}$ and $1 \mathrm{MeV}$ was evaluated for seven spectra, compiled in IAEA Technlcal Report $180 .^{2}$ The spectra are described as follows: 
- Health Physics Research Reactor (HPRR) ${ }^{3}$ at the Oak Ridge National. Laboratory-unshielded. (p. 58)

- HPRR shieided with $12 \mathrm{~cm}$ Lucite. (p. 58)

- HPRR shielded with $13 \mathrm{~cm}$ steel. (p. 58)

- Critical fissile $\mathrm{H}_{2} \mathrm{O}$ solution of spherical geometry, $30 \mathrm{~cm}$ in radius. (p. 64)

- 4,0 -moderated fission neutrons leaking through concrete of spherical geometry, $20 \mathrm{~cm}$ in radius. (p. 114)

- $\mathrm{H}_{2} \mathrm{O}$-moderated fission neutrons leaking through concrete of spherical geometry, $40 \mathrm{~cm}$ in radius. (p. 114)

- Fission neutrons leaking through spherical geometry of $D_{2} 0,30 \mathrm{~cm}$ in radius. (p. 74)

III. THEORETICAL CONSIDERATIONS

The observed activity, $\mathrm{A}$, of the ${ }^{64} \mathrm{Cu}$ can be related to the neutron flux density $\frac{\mathrm{d} \phi}{\mathrm{dE}}$, the reaction cross section $\sigma(E)$. the ${ }^{63} \mathrm{Cu}$ mass $\mathrm{m}$, and the time $t$ passed from irradiation to measurement. The activity is expressed as

$$
A=k \cdot m \cdot\left(1-e^{-\lambda T}\right) e^{-\lambda t} \int_{E_{c}}^{\infty} \sigma(E) \cdot \frac{d \phi(E)}{d E} d E
$$

In Eg. (2), $k$ is a constant, $T$ is the irradiation period, $\lambda$ is the decay constant for ${ }^{64} \mathrm{Cu}$, and $E_{c}$ is the cadmium cutoff energy $(\sim 0.5 \mathrm{eV})$.

The ${ }^{63} \mathrm{Cu}(n, \gamma){ }^{64} \mathrm{Cu}$ cross section has a $\frac{1}{\sqrt{E}}$ behavior with resonances mainly in the region of 0.5 to $10 \mathrm{keV}$; thus the fluence is not sampled uniformly in the $E_{c}$ to $1-\mathrm{HeV}$ energy region. Fluence at the low-energy part might dominate the measured quantity A [see Eq. (2)].

The dose in the $E_{c}$ to $15-M e V$ energy region can be written as

$$
D=\int_{E_{c}}^{15 \mathrm{MeV}} d(E) \cdot \frac{d \phi(E)}{d E} d E
$$

where $d(E)$ are the Pluence-to-dose conversion factors ${ }^{4}$ that include the ${ }^{1} H(n, \gamma)^{2} H$ component. A quantity similar to $D$ can be defined for the kerma and is denoted by $K$. The correspondinp conversion factors are denoted by $k(E) .4$ 
The conversion factors of Reference 4 are not the same as those used in the calculations of Auxier, et $a .^{5}$ in volume element number 57 of a tissue-equivalent phantom. However, the differences do not change significantly the derived quantilies $D$ and $K$.

The quantities $D$ and $K$ are not measured directly. Their evaluation is based on the assumption that effective cross sections and effective dose or kerma conversion factors can be defined. These, in turn, depend on the shape of the neutron spectrum investigated. The effective cross section and dose conversion factors for the energy region above $E_{c}$ are defined as follows:

$$
\bar{\sigma}=\frac{\int_{C}^{\infty} \frac{d \phi}{d E} \cdot \sigma(E) d E}{\int_{c}^{\infty} \frac{d \phi(E)}{d E} d E}=k_{1} \cdot \frac{A}{\phi} \text {. }
$$

and

$$
\bar{d}=\frac{\int_{c}^{\infty} d(E) \cdot \frac{d \phi(E)}{d E} d E}{\int_{c}^{\infty} \frac{d \phi(E)}{d E} d E} .
$$

Thus

$$
D=\bar{\phi} \cdot \bar{d} .
$$

where $k_{1}$ is a constant, $A$ is the measured activity, $\bar{\phi}$ is the total fluence above $E_{c}$, and $\bar{d}$ is the average fluence-to-dose conversion factor. 


\section{CALCULATED QUANTITIES}

Because the measured quantity is proportional to

$$
\int_{E_{c}}^{\infty} \frac{d \phi(E)}{d E} \cdot \sigma(E) d E
$$

calculations were performed to determine which energy bins in the $E_{c}$ to $15-\mathrm{MeV}$ range are contributing dominantly to the integral given in Eq. (7) for the various spectra investigated. The spectra between $E_{c}$ and $15 \mathrm{MeV}$ were divided into four energy groups: $E_{c}-15 \mathrm{keV}, 15-200 \mathrm{keV}, 200 \mathrm{keV}-1 \mathrm{MeV}$, and 1-15 MeV. In each energy bin the following quantities were calculated:

$$
\int_{E_{1}}^{E_{2}} \frac{d \phi(E)}{d E} \cdot \sigma(E) d E
$$

$$
\int_{E_{1}}^{E_{2}} \frac{d \phi(E)}{d E} d E
$$

$$
\int_{E_{1}}^{E_{2}} d(E) \cdot \frac{d \phi(E)}{d E} d E
$$

and similarly for the kerma. The effective cross section, dose, and kerma were also calculated. 
v. PARAHETERIZation OF THE ${ }^{63} \mathrm{Cu}(n, \gamma){ }^{64} \mathrm{Cu}$ CROSS SECTION

The ${ }^{63} \mathrm{Cu}(\mathrm{n}, \mathrm{y})^{64} \mathrm{Cu}$ cross section of the ENDF/B-IV Dosimetry File ${ }^{6,7,8}$ was parameterized in terms of analytic functions. These parameterized functions provide a convenient method for integration. The functions reproduce quite satisfactorily the experimental cross sections.

In the energy region of $E_{c}$ to $150 \mathrm{eV}$, the cross section is represented by

$$
\sigma(\text { barns })=\frac{0.7115}{\sqrt{E}}
$$

where $E$ is given in $\mathrm{eV}$. This formula has been derived by a one-parameter fit to the ENDF/B-IV $6,7,8$ data.

In the energy region from $150 \mathrm{eV}$ to $15 \mathrm{keV}$,

$$
\sigma(\text { barns })=a+\sum_{i=1}^{6} R_{i}
$$

where $a=0.06$ barns ( $a$ constant contribution in the resonance region) and $R_{i}$ represents resonances at six energies: $0.58,2,2.66,5.3,10$, and $12.5 \mathrm{keV}$. The constant cross section, $a$, was added to take into account the $\frac{1}{v}$ component and also some overlapping resonances that are not taken into account in the single-level Breit-Wigner formulae expressed as follows:

$$
\begin{aligned}
& R_{1}=\frac{1.47 \cdot 10^{-4}}{(E-0.58)^{2}+4.9 \cdot 10^{-7}}, \\
& R_{2}=\frac{1.45 \cdot 10^{-3}}{(E-2)^{2}+4.84 \cdot 10^{-4}},
\end{aligned}
$$




$$
\begin{aligned}
& R_{3}=\frac{2.76 \cdot 10^{-6}}{(E-2.66)^{2}+5.52 \cdot 10^{-6}}, \\
& R_{4}=\frac{1.6 \cdot 10^{-3}}{(E-5.3)^{2}+4 \cdot 10^{-4}} \\
& R_{5}=\frac{9 \cdot 10^{-3}}{(E-10)^{2}+9 \cdot 10^{-4}} \\
& R_{6}=\frac{4.69 \cdot 10^{-6}}{(E-12.5)^{2}+1.56 \cdot 10^{-6}}
\end{aligned}
$$

The cross sections $R_{1}$ are in barns and the energy $E$ is in keV. All of the above expressions are derived with the assumption that the nucleus is at rest; no further broadening (Doppler correction) is taken into account.

In the region between $15 \mathrm{keV}$ and $15 \mathrm{MeV}$, the cross section is represented by

$$
\sigma(\text { barns })=\frac{0.181}{E^{0.408}},
$$

where $E$ is given in keV. This formula was obtained by using a two-parameter fit to match the cross section at $15 \mathrm{keV}$ given by Eq. (12) and to match the $(n, y)$ cross section at $1 \mathrm{MeV}$.

VI. DESCRIPTION OF CALCULATION ROUTINES

A program for calculating the quantities mentioned above was written in BASIC on a HP-9845B microcomputer. The integrations were performed separately in the four energy groups described previously. Two equivalent methods of 
Integration were employed in the program, basically to check the accuracy of the numerical integration procedure. They are expressed as follows:

$$
I=\int_{E_{1}}^{E_{2}} \frac{d \phi}{d E} \cdot f(E) d E
$$

and

$$
I_{1}=\int_{E_{1}}^{E_{2}} \frac{d \phi}{d E} \cdot E \cdot f(E) d(\ln E)
$$

where $f(E)$ is either a cross section or fluence-to-dose (or kerma) conversion factor.

Tabulated spectra are presented in IAEA-180 in a histogram form. Rather than considering $\frac{\mathrm{d} \phi}{\mathrm{dE}}$, the authors tabulate values of $E \cdot \frac{\mathrm{d} \phi}{\mathrm{dE}}$. This function is smooth and slowly varying and therefore can be easily interpolated. On the other hand, the function $\frac{\mathrm{d} \phi}{\mathrm{dE}}$ usually has a large negative slope at low energies. The energy associated with the fluence value in the IAEA-180 tables corresponds to the upper limit of the histogram interval. All interpolations have been performed on $\mathrm{E} \cdot \frac{\mathrm{d} \phi}{\mathrm{dE}}$ rather than on $\frac{\mathrm{d} \phi}{\mathrm{dE}}$.

The quantities $E \cdot \frac{d \phi}{d E}$ and the fluence-to-dose and kerma conversion factors, $d(E)$ and $k(E)$ respectively, are smooth functions. Thus, interpolations at energies between those provided in Refs. 2 and 4 were performed both linearly on a standard plot and linearly on a semilog plot. If $g(x)$ is the function to be linearly interpolated at a point $x_{1}<x_{0}<x_{2}$, then

$$
g\left(x_{0}\right)=g\left(x_{1}\right)+\frac{g\left(x_{2}\right)-g\left(x_{1}\right)}{x_{2}-x_{1}} \cdot\left(x_{0}-x_{1}\right) .
$$


Linear interpolation on a semilog plot is described by

$$
g\left(x_{0}\right)=g\left(x_{1}\right)+\frac{g\left(x_{2}\right)-g\left(x_{1}\right)}{\log \left(\frac{x_{2}}{x_{1}}\right)} \cdot \log \left(\frac{x_{0}}{x_{1}}\right) .
$$

The integrals $I$ or $I_{1}$, given in Eqs. (20) and (21), were calculated by using either the trapezoidal method or the Simpson one-third rule.

When the integrals in the form I [Eq. (20)] were evaluated, various energy step sizes were applied. They ranged from $0.25 \mathrm{eV}$ to $1 \mathrm{eV}$ in the region of $e_{c}$ to $15 \mathrm{keV}$, from $500 \mathrm{eV}$ to $1 \mathrm{keV}$ in the region of $15 \mathrm{keV}$ to $1 \mathrm{MeV}$, and $10 \mathrm{keV}$ in the region of 1 to $15 \mathrm{MeV}$.

When the integrals in the form $I_{1}[E q$. (21)] were evaluated, the energy step sizes were not constant, but rather increased with energy. For instance, If the step size $\mathrm{df}=\frac{\mathrm{dE}}{\mathrm{E}}$ were $1.72 \cdot 10^{-4}$, then $\mathrm{dE}$ near the main resonance of $580 \mathrm{eV}$ is $0.1 \mathrm{eV}$, whereas its value is about $0.86 \mathrm{eV}$ at $5 \mathrm{keV}$. Variations of no more than $10 \%$ in the integral

$$
\int_{E}^{15} k e V
$$

were observed between procedures mentioned above. The integrals in the region from $15 \mathrm{keV}$ to $15 \mathrm{MeV}$ were relatively insensitive to the step sizes and to the integration methods used. Normalizations of the total fluences were compared with those given in Ref. 2 and differences were no more than $5 \%$.

\section{RESULTS}

Relative dose and kerma contributions are shown in Tables I and II for the spectra of interest and for the energy groups previously described. The contribution of neutrons with energies below $E_{c}$ to the dose and kerma for all spectra investigated is at most $5 \%$ and is not included in the tabulations. The percentages are normalized to the energy region from $E_{c}$ to $15 \mathrm{MeV}$. 
TABLE I

RELATIVE DOSE CONTRIBUTIONS

\begin{tabular}{|c|c|c|c|c|c|}
\hline & Spectrum & $E_{e}-15 \mathrm{keV}$ & $15-200 \mathrm{keV}$ & $200 \mathrm{keV}-1 \mathrm{MeV}$ & $1-15 \mathrm{HeV}$ \\
\hline 1 & HPRR (Unshielded) & 0.8 & 2.4 & 19.5 & 77.3 \\
\hline 2 & $\begin{array}{l}\text { HPRR (Shielded } \\
\text { with } 12 \mathrm{~cm} \text { Lucite) }\end{array}$ & 0.5 & 7.7 & 12.4 & 79.4 \\
\hline 3 & $\begin{array}{l}\text { HPRR (Shielded } \\
\text { with } 13 \mathrm{~cm} \text { steel) }\end{array}$ & 0.5 & 5.3 & 44.0 & 50.1 \\
\hline 4 & $\begin{array}{l}\text { Fissile } \mathrm{H}_{2} \mathrm{O} \text { solu- } \\
\text { tion, } 30-\mathrm{cm} \text { radius }\end{array}$ & 3.2 & 3.2 & 16.5 & 77.1 \\
\hline 5 & $\begin{array}{l}\mathrm{H}_{2} \mathrm{O} \text {-moderated } \\
\text { flssion neutrons } \\
\text { leaking through } \\
20 \mathrm{~cm} \text { concrets }\end{array}$ & 14.2 & 6.6 & 16.7 & 62.5 \\
\hline 6 & $\begin{array}{l}\mathrm{H}_{2} \mathrm{O} \text {-moderated } \\
\text { fission neutrons } \\
\text { leaking through } \\
40 \mathrm{~cm} \text { concrete }\end{array}$ & 13.6 & 4.7 & 13.6 & 68.1 \\
\hline 7 & $\begin{array}{l}\text { Bssion neutrons } \\
\text { 1 eaking through } \\
30 \mathrm{~cm} \mathrm{D_{2 }} \text { o }\end{array}$ & 40.2 & 6.9 & 5.3 & 47.6 \\
\hline
\end{tabular}

In percentages of the total dose in the $\mathrm{E}_{\mathrm{c}}$ to $15 \mathrm{HeV}$ region. 
TABLE II

RELATIVE KERMA CONTRIBUTIONS ${ }^{a}$

\begin{tabular}{|c|c|c|c|c|c|}
\hline & Spectrum & $E_{c}-15 \mathrm{keV}$ & $15-200 \mathrm{keV}$ & $200 \mathrm{keV}-1 \mathrm{MeV}$ & $1-15 \mathrm{MeV}$ \\
\hline 1 & HPRR (Unshielded) & 0.1 & 2.3 & 20.2 & 77.4 \\
\hline 2 & $\begin{array}{l}\text { HPRR (Shielded } \\
\text { with } 12 \mathrm{~cm} \\
\text { Lucite }\end{array}$ & 0.3 & 3.2 & 13.4 & 83.1 \\
\hline 3 & $\begin{array}{l}\text { HPRR (Shlelded } \\
\text { w1th } 13 \mathrm{~cm} \\
\text { steel) }\end{array}$ & 0 & 5.2 & 44.9 & 49.9 \\
\hline 4 & $\begin{array}{l}\text { Fissile } \mathrm{H}_{2} \mathrm{O} \text { solu- } \\
\text { tion, } 30-\mathrm{E}_{\mathrm{a}} \\
\text { radius }\end{array}$ & 0.1 & 3.1 & 17.5 & 79.3 \\
\hline 5 & $\begin{array}{l}\mathrm{H}_{2} \mathrm{O} \text {-noderated } \\
\text { fission neutron } \\
\text { leaking through } \\
20 \mathrm{~cm} \text { concrete }\end{array}$ & 0.8 & 6.9 & 20.0 & 72.3 \\
\hline 6 & $\begin{array}{l}\mathrm{H}_{\mathrm{O}} \mathrm{O} \text {-moderated } \\
\text { fission neutron } \\
\text { leaking through } \\
\text { no } \mathrm{cm} \text { concrete }\end{array}$ & 0.6 & 4.9 & 16.2 & 78.3 \\
\hline 7 & $\begin{array}{l}\text { Fission neutrons } \\
\text { leaking through } \\
30 \mathrm{cu} \mathrm{D}_{2} \mathrm{O}\end{array}$ & 2.5 & 9.6 & 9.0 & 78.9 \\
\hline
\end{tabular}

In percentages of the total kerma in the $E_{c}$ to 15HeV region. 
Table III summarizes the relative contributions of the quantities

$$
\int_{E_{1}}^{E_{2}} \frac{d \phi(E)}{d E} \cdot \sigma(E) d E
$$

and

$$
\int_{E_{1}}^{E_{2}} \frac{d \phi(E)}{d E} d E
$$

The results shown in Tables I-III clearly indicate the dominance of the $E_{c}$ to 15-keV energy range to the ${ }^{64} \mathrm{Cu}$ activity, and the dominance of the $15-\mathrm{keV}$ to 15-MeV energy range to the dose and kerma contributions.

The dose or kerma is found experimertally by using spectrum weighted effective cross sections and effective fluence-to-dose (or kerma) conversion factors. Since $\bar{\sigma}, \bar{d}$, and $\bar{k}$ are not additive quantities in the various energy groups, they are summarized in Table IV in cumulative energy bins, i.e..

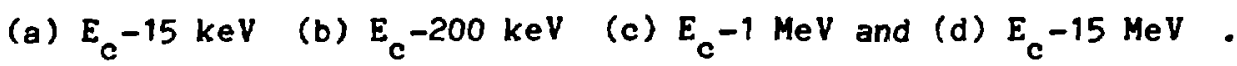

The effective cross sections, $\bar{\sigma}$, are given in barns whereas the effective fluevie-to-dose (or kerixa) conversion factors are given in units of $10^{-10}$ $\mathrm{rad} / \mathrm{n} / \mathrm{cm}^{2}$.

\section{EVALUATION OF ACTIVITY WITH ${ }^{10}$ B ABSORBER}

The contribution of the low energies to the measured activity can be decreased by surrounding the ${ }^{63} \mathrm{Cu}$ foil with thick ${ }^{10}{ }_{B}$ material. 9 The effect of the ${ }^{10} \mathrm{~B}$ shield on the measured activity was evaluated for $\mathrm{H}_{2} \mathrm{O}$-moderated fission neutrons passing through $20 \mathrm{~cm}$ concrete. The ${ }^{10_{B}}$ shields varied between 0.3 $\mathrm{B} / \mathrm{cm}^{2}$ and $1.5 \mathrm{~g} / \mathrm{cm}^{2}$, and the ${ }^{10} \mathrm{~B}$ cross section was parameterized as follows: 


$$
\sigma_{B}(\text { barn })=\frac{G 11}{E} \text {. }
$$

where $E$ is the neutron energy in $\mathrm{eV}$.

TABLE III

RELATIVE CONTRIBUTIOHS OF QUANTITIES GIVEN IN EQS. (24) AND (25)

\begin{tabular}{|c|c|c|c|c|c|c|}
\hline & Spectrum & & $E_{c}-15 k e Y$ & $15-200 \mathrm{keV}$ & $200 \mathrm{keV}-1 \mathrm{MeV}$ & $1-15 \mathrm{MeV}$ \\
\hline 1 & $\begin{array}{l}\text { HPRR } \\
\text { (Unshielded) }\end{array}$ & $\begin{array}{l}(24) \\
(25)\end{array}$ & $\begin{array}{r}63.5 \\
6.2\end{array}$ & $\begin{array}{l}9.5 \\
9.4\end{array}$ & $\begin{array}{l}13.0 \\
28.6\end{array}$ & $\begin{array}{l}14.0 \\
55.8\end{array}$ \\
\hline 2 & $\begin{array}{l}\text { HPAR (Shielded } \\
\text { with } 12 \mathrm{~cm} \\
\text { Lucite) }\end{array}$ & $\left|\begin{array}{l}(24) \\
(25)\end{array}\right|$ & $\begin{array}{l}91.9 \\
30.5\end{array}$ & $\begin{array}{r}3.5 \\
11.9\end{array}$ & $\begin{array}{r}1.8 \\
14.9\end{array}$ & $\begin{array}{r}2.8 \\
42.7\end{array}$ \\
\hline 3 & $\begin{array}{l}\text { HPRR (Shielded } \\
\text { with } 13 \mathrm{~cm} \\
\text { steel) }\end{array}$ & $\begin{array}{l}(24) \\
(25)\end{array}$ & $\begin{array}{r}44.4 \\
3.7\end{array}$ & $\begin{array}{l}16.5 \\
14.7\end{array}$ & $\begin{array}{l}29.1 \\
50.9\end{array}$ & $\begin{array}{l}10.0 \\
30.7\end{array}$ \\
\hline 4 & $\begin{array}{l}\text { Fissile } \mathrm{H}_{2} \mathrm{O} \\
\text { solution, } \\
30-\mathrm{cm} \text { radius }\end{array}$ & $\begin{array}{l}(24) \\
(25)\end{array}$ & $\begin{array}{l}87.2 \\
21.9\end{array}$ & $\begin{array}{r}4.9 \\
11.6\end{array}$ & $\begin{array}{r}3.7 \\
20.9\end{array}$ & $\begin{array}{r}4.2 \\
45.7\end{array}$ \\
\hline 5 & $\begin{array}{l}\mathrm{H}_{2} \mathrm{O} \text {-moderated } \\
\text { ffssion neu- } \\
\text { trons leaking } \\
\text { through } 20 \mathrm{~cm} \\
\text { concrete }\end{array}$ & $\begin{array}{l}(24) \\
(25)\end{array}$ & $\begin{array}{l}95.5 \\
52.6\end{array}$ & $\begin{array}{r}2.7 \\
14.1\end{array}$ & $\begin{array}{r}0.9 \\
12.4\end{array}$ & $\begin{array}{r}0.7 \\
20.9\end{array}$ \\
\hline 6 & $\begin{array}{l}\mathrm{H}_{2} \mathrm{O} \text {-moderated } \\
\text { ffssion neu- } \\
\text { trons leaking } \\
\text { through } 40 \mathrm{~cm} \\
\text { concrete }\end{array}$ & $\begin{array}{l}(24) \\
(25)\end{array}$ & $\begin{array}{l}96.1 \\
54.0\end{array}$ & $\begin{array}{r}2.1 \\
10.6\end{array}$ & $\begin{array}{r}0.8 \\
10.7\end{array}$ & $\begin{array}{r}1.0 \\
24.7\end{array}$ \\
\hline 7 & $\begin{array}{l}\text { Fission neu- } \\
\text { trons leaking } \\
\text { through } 30 \mathrm{~cm} \\
\mathrm{D}_{2} \mathrm{O}\end{array}$ & $\begin{array}{l}(24) \\
(25)\end{array}$ & $\begin{array}{l}98.2 \\
80.5\end{array}$ & $\begin{array}{l}1.4 \\
9.4\end{array}$ & $\begin{array}{l}0.1 \\
2.2\end{array}$ & $\begin{array}{l}0.3 \\
7.9\end{array}$ \\
\hline
\end{tabular}

an percentages of the Integrals from $\mathrm{E}_{\mathrm{c}}$ to $15 \mathrm{MeV}$. 
TABLE IV

AVERAGE CROSS SECTIONS AND FLUENCE-TO-DOSE (KERHA) CONVERSION FACTORS

\begin{tabular}{|c|c|c|c|c|c|c|}
\hline & Spectrum & & $-15 \mathrm{keV}$ & $E_{c}-200 \mathrm{keV}$ & $\mathrm{E}_{c}-1 \mathrm{MeV}$ & $E_{c}-15 \mathrm{MeV}$ \\
\hline 1 & HPRR (Unshielded) & $\frac{\bar{\sigma}}{\bar{k}}$ & $\begin{array}{l}0.313 \\
3.54 \\
0.23\end{array}$ & $\begin{array}{l}0.144 \\
5.89 \\
3.70\end{array}$ & $\begin{array}{r}0.06 \\
14.82 \\
12.39\end{array}$ & $\begin{array}{l}0.035 \\
28.9 \\
23.9\end{array}$ \\
\hline 2 & $\begin{array}{l}\text { HPRR (Shielded } \\
\text { with } 12 \mathrm{~cm} \\
\text { Lucite) }\end{array}$ & $\frac{\bar{d}}{\bar{d}}$ & $\begin{array}{l}0.333 \\
3.67 \\
0.15\end{array}$ & $\begin{array}{l}0.249 \\
4.5 \\
1.5\end{array}$ & $\begin{array}{l}0.188 \\
8.33 \\
5.5\end{array}$ & $\begin{array}{l}0.111 \\
23.2 \\
18.7\end{array}$ \\
\hline 3 & $\begin{array}{l}\text { HPRA (Shlelded } \\
\text { with } 13 \mathrm{en} \\
\text { steel) }\end{array}$ & $\frac{\vec{\sigma}}{\bar{d}}$ & $\begin{array}{l}0.303 \\
3.5 \\
0.15\end{array}$ & $\begin{array}{l}0.084 \\
7.0 \\
5.2\end{array}$ & $\begin{array}{l}0.033 \\
15.6 \\
13.4\end{array}$ & $\begin{array}{l}0.026 \\
21.7 \\
18.5\end{array}$ \\
\hline 4 & $\begin{array}{l}\text { Fissile } \mathrm{H}_{2} \mathrm{O} \\
\text { solution, }{ }^{30} \mathrm{~cm} \\
\text { radius }\end{array}$ & $\frac{\bar{\sigma}}{\bar{d}}$ & $\begin{array}{l}0.323 \\
3.6 \\
0.18\end{array}$ & $\begin{array}{l}0.224 \\
4.7 \\
1.9\end{array}$ & $\begin{array}{l}0.143 \\
10.3 \\
7.6\end{array}$ & $\begin{array}{l}0.081 \\
24.3 \\
19.9\end{array}$ \\
\hline 5 & $\begin{array}{l}\mathrm{H}_{2} \mathrm{O} \text {-moderated } \\
\text { fission neutrons } \\
\text { leak Ing through } \\
20 \mathrm{~cm} \text { concrete }\end{array}$ & $\frac{\bar{\sigma}}{\bar{d}}$ & $\begin{array}{l}0.339 \\
3.7 \\
0.14\end{array}$ & $\begin{array}{l}0.274 \\
4.3 \\
1.1\end{array}$ & $\begin{array}{l}0.234 \\
6.5 \\
3.5\end{array}$ & $\begin{array}{l}0.187 \\
13.8 \\
10.1\end{array}$ \\
\hline 6 & $\begin{array}{l}\text { H O-moderated } \\
\text { rfssion neutrons } \\
\text { leaking through } \\
40 \mathrm{~cm} \text { concrete }\end{array}$ & $\frac{\bar{\sigma}}{\overline{\mathbf{d}}}$ & $\begin{array}{l}0.321 \\
3.7 \\
0.12\end{array}$ & $\begin{array}{l}0.275 \\
4.2 \\
0.93\end{array}$ & $\begin{array}{l}0.238 \\
6.3 \\
3.2\end{array}$ & $\begin{array}{l}0.181 \\
14.9 \\
10.9\end{array}$ \\
\hline 7 & $\begin{array}{l}\text { Fission neutrons } \\
\text { leaking through } \\
30 \mathrm{~cm} \mathrm{D}_{2} \mathrm{O}\end{array}$ & $\frac{\bar{\sigma}}{\bar{d}}$ & $\begin{array}{l}0.311 \\
3.7 \\
0.12\end{array}$ & $\begin{array}{l}0.283 \\
3.9 \\
0.5\end{array}$ & $\begin{array}{l}0.277 \\
4.2 \\
0.9\end{array}$ & $\begin{array}{l}0.255 \\
7.4 \\
3.8\end{array}$ \\
\hline
\end{tabular}


The measured activity is therefore proportional to the following quantity:

$$
c=\int_{E_{c}}^{15 \mathrm{MeV}} \frac{d \phi(E)}{d E} \cdot \sigma(E) \cdot \exp \left[-0.06 \cdot \sigma_{B}(E) \cdot t\right] d E .
$$

where $t$ is the $10_{B}$ thickness in $g / \mathrm{cm}^{2}$ and the factor 0.06 is derived from Avogadro's number divided by the mass of $10_{B}$.

Table $V$ sumarizes the quantity given in $\mathrm{Eq}$. (27) as a function of the ${ }^{10_{B}}$ thickness for each of the four energy groups. The quantity $C$ is given as a percentage of the total energy region between $E_{c}$ and $15 \mathrm{MeV}$. The decrease in the measured activity as a function of the ${ }^{10} \mathrm{~B}$ thickness is apparent from this table.

TABLE Y

THE EFFECT OF ${ }^{10}$ B SHIELDS ${ }^{a}$

\begin{tabular}{|c|c|c|c|c|c|}
\hline \multirow[b]{2}{*}{$\begin{array}{l}10_{B} \text { Thickness } \\
\left(\mathrm{B} / \mathrm{cm}^{2}\right)\end{array}$} & \multirow[b]{2}{*}{$\begin{array}{l}\text { Remainder } \\
\text { of activity } \\
\text { in the } \\
\text { E co 15-keV }_{\text {cogion }}\end{array}$} & \multicolumn{4}{|c|}{$c^{b}$} \\
\hline & & $E_{c}-15 \mathrm{keV}$ & $15-200 \mathrm{keV}$ & $200 \mathrm{keV}-1 \mathrm{MeV}$ & $1-15 \mathrm{MeV}$ \\
\hline 0 & 1 & 95.5 & 2.7 & 0.9 & 0.7 \\
\hline 0.3 & 0.41 & 87.8 & 7.5 & 2.6 & 2.1 \\
\hline 0.9 & 0.21 & 77.2 & 14.2 & 4.8 & 3.8 \\
\hline 1.5 & 0.09 & 63.7 & 22.1 & 8.0 & 6.2 \\
\hline
\end{tabular}

-Results are for $\mathrm{H}_{2} \mathrm{O}$-moderated fission neutrons leaking through $20 \mathrm{~cm}$ concrete.

byalues of C [Eq. (27)] are renormalized for each ${ }^{10} B$ thickness and given as percentages of the total region, $E_{c}-15$ MeV. 
IX. DISCUSSION

The spectra investigated, especially 1-6, represent typical criticality accident situations. Criticality accidents with $\mathrm{D}_{2} \mathrm{O}$ moderation are highly improbable at the Los Alamos National Laboratory.

Results in tables (I) and (II) show that the main contributions (about $80 \%$ or more) to the dose and the kerma for spectra 1-6 originate from the region of $200 \mathrm{keV}$ to $15 \mathrm{MeV}$. It can also be seen that the dose and kerma contributions from the region of $15 \mathrm{keV}$ to $1 \mathrm{MeV}$ are usually much larger than from the region of $E_{c}$ to $15 \mathrm{keV}$. The latter fact suggests that one should choose a dosimeter for the $E_{c}$ to $1-\mathrm{HeV}$ region that is mainly sensitive from $15 \mathrm{keV}$ to $1 \mathrm{MeV}$ and less sensitive in the $E_{c}$ to $15-\mathrm{keV}$ energy region.

Results from spectrum 7 indicate that the above situation might be different if the fission spectrum is shielded by thick materials not containing hydrogen. In addition to $\mathrm{D}_{2} \mathrm{O}$, one might consider graphite (thicker than 40 clis), Iron (thicker than $50 \mathrm{~cm}$ ), copper (thicker than $40 \mathrm{~cm}$ ), and heavy materials such as lead (thicker than $70 \mathrm{~cm}$ ). However, use of these spectra is not realistic in current Laboratory operations. Clearly, when the dosimeter is designed, the spectra for the most probable scenario should be taken into consideration.

Table III shows that although the dose and kerma originate primarily from the region above $15 \mathrm{keV}$, the measured quantity given in $\mathrm{Eq}$. (7) (using the ${ }^{63} \mathrm{Cu}$ activation foll) is dominated by the region of $E_{c}$ to $15 \mathrm{keV}$, that is,

$$
\int_{E_{c}}^{15 \mathrm{keV}} \frac{\mathrm{d \phi}(E)}{\mathrm{dE}} \cdot \sigma(E) \mathrm{dE} \gg \int_{15 \mathrm{keV}}^{1 \mathrm{MeV}} \frac{\mathrm{d \phi}(E)}{\mathrm{dE}} \cdot \sigma(E) \mathrm{dE}
$$

\footnotetext{
Information available from T. McLaughlin, Group HSE-6, Los Alamos National Laboratory .
} 
It can be concluded that ${ }^{63} \mathrm{Cu}$ samples the fluence primarily in the energy region from $E_{c}$ to $15 \mathrm{keV}$, where the dose contribution is expected to be small.

In reality, even when theoretical spectra calculations are relied upon, uncertainties in the low-energy part of the spectrum (which usually occur because of room scattering) might lead to large deviations in the ${ }^{64} \mathrm{Cu}$ activity, given mainly by the integral

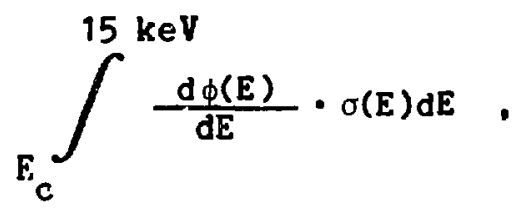

and thus lead to deviations in the derived dose. However, in practice, these changes in the spectrum do not significantly affect the dose contribution.

Table IV shows how $\bar{\sigma}$ varies for each of the four energy bins. In principle, one measures a quantity proportional to that given in Eq. (7). Although the major contribution to this integral is generally from the low-energy region $\left(E_{c}-15 \mathrm{keV}\right), \bar{\sigma}$ is influenced heavily by the high-energy regions (because the fluence contribution increases). Therefore, the use of $\bar{\sigma}$, by taking into account the fluence over the full energy range $E_{c}$ to $15 \mathrm{MeV}$ or $E_{c}$ to $1 \mathrm{MeV}$, leads to a decrease of $\bar{\sigma}$ and in turn increases the average $\bar{\phi}$. determined experimentally. The quantities $\bar{d}$ and $\bar{k}$ increase with the increasing size of the energy bin. Therefore, the products $\bar{\Phi}$ (or equivalently $\Phi \quad \bar{k}$ ) might increase twofold.

One can also observe that the effective cross section and the effective quantity $d$ are almost constant in the $E_{c}$ to 15-keV region, independent of the neutron spectra; $\bar{\sigma}=0.32$ barns and $\bar{d}=3.6 \cdot 10^{-10} \mathrm{rad} / \mathrm{n} / \mathrm{cm}^{2}$. It would be appropriate to claim that the ${ }^{63} \mathrm{Cu}$ activation foil covers the full range between $E_{c}$ and $1 \mathrm{MeV}$ but is dominated by the low-energy region from $E_{c}$ to 15 keV. Having the measured activity, $A$, one can determine the average fluence by dividing $A$ by 0.32 barn (assuming a thin target where self-absorption can be neglected). The dose $D_{1}$ will be defined as

$$
D_{1}(\operatorname{rad})=\frac{k_{1} A}{0.32} \cdot 3.6 \cdot 10^{-10} \text {, }
$$

where $k_{1}$ and $A$ are defined in Eq. (4). 
It should be emphasized that the dose, $D_{1}$, represents the region from $E_{c}$ to $15 \mathrm{keV}$, and it certainly underestimates the dose in the $E_{c}$ to $1-$ HeV region. When the fluence spectrum is more accurately known, Table IV can be used to obtain better estimates of the quantities $\bar{\sigma}$ and $\bar{d}$ and thus the dose and kerma in the region from $E_{c}$ to 1 MeV.

Table $V$ shows that it is possible to decrease the contribution of the $E_{c}$ to $15 \mathrm{keV}$ region to the measured activity. However, the amount of boron material needed is large and will appreclably increase the cost of the dosimeter and increase the lower limit of neutron detectability.

\section{REFERENCES}

1. D. G. Vasilik and R. W. Martin, "The Los Alamos Personnel and Area Criticality Dosimeter Systems," Los Alamos National Laboratory report LA-8848-MS (June 1981).

2. H. Ing and S. Makra, Compendium of Meutron Spectra in Criticality Accident Dosimetry. IAEA Technical Report Series Ho. 180 (Vienna, 1978).

3. C. S. Sims and G. G. Killough, "Reference Dosimetry for Various Health Physics Research Reactor Spectra," Oak Ridge National Laboratory report ORNL/TM-7748 (July 1981).

4. Dosimetry for Criticality Accidents: A Manual. IAEA Technical Report Series No. 211 (Vienna, 1982).

5. T. A. Auxier, W. S. Snyder, and T. D. Jones, Neutron Interactions and Penetration in Tissue," in Radiation Dosimetry, F. H. Attix and W. C. Roesch, Eds. (Academic Press, Inc.. New York, 1968), Vol. I, p. 275.

6. B. A. Magurno, Ed. NENDF/B-IV Dosimetry File, NNational Neutron Cross Section Center, Information Analysis Center," Brookhaven National Laboratory report BNL-NCS-50446 (April 1975).

7. D. I. Garber and R. R. Kinsey, "Neutron Cross Sections," Brookhaven National Laboratory report BNL-325, (January 1976).

8. S. F. Mughabghal, M. Divadeenam, and H. E. Holden, Heutron Cross Sections (Academic Press, Inc.. New York, 1981), Vol. I.

9. G. S. Hurst, J. A. Harter, F. M. Hensley, H. A. Mi:ls, M. Slater, and P. W. Reinhardt, Health Phys. 38, 1079 (1980). 